\title{
MOLE-RAT FROM KHORTYTSIA IN THE LIGHT OF MORPHOLOGICAL AND GEOGRAPHICAL RELATIONS BETWEEN SPALAX ZEMNI AND S. MICROPHTHALMUS
}

\author{
Marina Korobchenko, Igor Zagorodniuk \\ National Museum of Natural History, NAS of Ukraine (Kyiv) \\ Bohdan Khmelnytsky St. 15, Kyiv, 01030 Ukraine \\ e-mail: aquamarine@ukr.net; zoozag@ukr.net
}

\begin{abstract}
Mole-Rat from Khortytsia in the Light of Morphological and Geographical Relations between Spalax zemni and S. microphthalmus. - Korobchenko, M., Zagorodniuk, I. - The taxonomic status of the mole-rats from Khortytsia Island which is located between the ranges of Spalax zemni (right bank of the Dnipro) and S. microphthalmus (left bank) are considered. This island population is a unique biogeographical phenomenon that may be an evidence of ancient evolutionary events associated with the migration of steppe animals in the region of Zaporizhia Rapids. The mole-rat forms on Khortytsia a stable population, which is regarded as autochthonous. Osteological characters of mole rats from the island and adjacent areas of the right bank of the Dnipro, as well as comparison of these samples with those of S. zemni and S. microphthalmus from distant parts of their ranges were investigated. By all characters, mole rats of Khortytsia and adjacent areas of the left bank of the Dnipro should be identified as $S$. zemni. Authors suggest that the mole-rat population in the nearest left-bank steppes may also be $S$. zemni. Descriptions of craniological characters to distinguish the two species and their distribution map are presented.
\end{abstract}

Key words: mole-rat, Spalax, Khortytsia Island, species identification, biogeography, Ukraine.

Сліпак з Хортиці у світлі морфологічних та географічних взаємин Spalax zemni та S. microphthalmus. - Коробченко, М., Загороднюк, I. - Розглянуто таксономічний статус сліпаків з о. Хортиця, що лежить між ареалами Spalax zетni (правобережжя Дніпра) та S. microphthalmus (лівобережжя). Ця острівна популяція є унікальним біогеографічним феноменом, який може бути свідоцтвом давніх еволюційних подій, пов'язаних з міграціями степових видів тварин в районі Запорізьких порогів. Сліпак формує на Хортиці стабільну популяцію, яка розглядається як автохтонна. Досліджено остеологічні ознаки сліпака 3 цього острова та прилеглих до нього районів правобережжя і проведено порівняння цих зразків з вибірками $S$. zemni та $S$. microphthalmus з віддалених частин їх ареалів. За всіма ознаками сліпак з Хортиці та прилеглих до острова Хортиці територій лівобережжя Дніпра має бути ідентифікований як S. zemni. Припускається, що популяція сліпаків з найближчих лівобережних степах може також виявитися $S$. zemni. Наведено описи краніологічних ознак для розрізнення двох видів і карту їх поширення в регіоні.

Ключов і слова: сліпак, Spalax, острів Хортиця, видова діагностика, біогеографія, Україна.

\section{Introduction}

There are five morphologically close species of mole-rats (Spalacidae) in the Ukrainian fauna, whose reliable diagnosis, as well as taxonomical and biogeographical reconstructions for which are possible, when craniological characters such as proportions of the skull, some details of its structure and the morphology of the tooth surface are analyzed (Решетник, 1941; Топачевський 1969). Тhe peculiarity of this group is the extremely high morphological similarity. Hence, species of mole-rats, occupying almost identical econiches, in fact are strictly allopatric everywhere they occur, and they do not form sympatric settlements. Borders between their ranges, as a rule, are major river valleys, i.e. rivers are key biogeographic coordinates (Загороднюк, 1999). One of such coordinates is the course of the Dnipro, which is a border in distribution of three of five species known in the fauna of Ukraine - Spalax microphthalmus, S. zemni and S. arenarius (Коробченко, Загороднюк, 2009). 
One of the main biogeographical "bridges" on the Dnipro is the region of Dnipro Rapids. It is known that in this place intensive faunal exchanges occurred between terrestrial faunas of the leftand right banks of the Dnipro. In particular, in this very area took place the formation of a small but viable group of settlements of the steppe northern mole-rat (Ellobius talpinus) and the great jerboa (Allactaga major): these species, which are distributed mostly in the left bank steppes, form in the region of Zaporizhia Rapids and the Lower Dnipro a series of settlements that occur throughout the right bank from Zaporizhia to Kherson (Селюніна, 2008; Коробченко та ін., 2014).

Especially important are the findings of species limited in their distribution by the Dnipro river, but also occurring on its islands. One of the best known biogeographical units on the Dnipro is the region of Zaporizhia Rapids, especially Khortytsia Island, located near Zaporizhia city. This sizable island is characterized by steppe communities belonging to the Khortytsia National Reserve. Such material is extremely valuable for research on possible faunal exchanges between the right- and left bank parts of the steppe, and it can "carry" the memory of the ancient states of fauna that have survived in conditions of island isolation.

The goal of this work is to analyze the morphological characters of mole-rats from Khortytsia and surrounding areas in comparison with S. zemni and S. microphthalmus, as well as determination of spatial relations between these two species in terms of the hypothesis about faunal exchanges in the region of Dnipro Rapids.

\section{Material and methods}

The present work was based on the osteological collection of mole-rats preserved in the National Museum of Natural History (NMNH), and on several samples handed to us from the region of our special attention - Khortytsia and adjacent areas. The key objects of our analysis are a sample captured on Khortytsia and a series of examples from the closest to Khortytsia sites near Zaporizhia city (right bank of the Dnipro). For comparison, several samples of mole-rats from more distant areas, preserved in NMNH and described earlier, were analyzed (Коробченко, 2014).

Problematic samples (preserved as "S. microphthalmus"): 1 ex., sen. (worn teeth), Khortytsia (Zaporizhia reg.), found in ca. 1990-2000, deposited in the collection of archeologists in Zaporizhia University, handed by O. Tuboltsev (another "mole-rat" specimen from the same site turned out to be a combination of a skull of Ondatra and a mandible of Spalax, without reliable diagnostic characters $\left.{ }^{1}\right) ; \cdot 5$ mole-rat skulls ("S. microphthalmus"), 4 subad. +1 ad., collected in the nearest to Khortytsia sites of the Dnipro region, within the urban area of Zaporizhia city on 11.05.2003, in its left-bank part (preserved in the work collection of N. Lebedieva, Zaporizhia University);

Podolian mole-rat: 12 samples of S. zemni, collected in the Mykolaiv reg. (Shyrokyi Lan military training ground) by K. Redinov in 07.2005 in nests of raptors and passed to the authors, now preserved in NMNH (only 2 complete skulls in the series, the rest represents isolated mandibles); $\bullet 2$ samples of S. zemni from the collection of L. Mehely, collected in Yavoriv dist. ("Janow" = Ivano-Frankove), Lviv reg. in 1870 («№ 262, typus discriptionis») $)^{2}$ and in Galych dist. (Kasova Hora), Ivano-Frankivsk reg. in 05.1937 (№ 630); • a series of S. zemni collected by E. Reshetnyk in 1937-1938, 10 mole-rat skulls from different districts of Right-Bank Ukraine (Mykolaiv, Dnipropetrovsk, Odessa regions), preserved in the collection of the Paleontological Department of NMNH (Коробченко, 2014);

Eastern mole-rat: - comparative collection of S. microphthalmus amassed by the authors in 20072014, about 46 mole-rat skulls from different districts of Left-Bank Ukraine, mainly from the Luhansk reg. (samples of different periods collected by the authors or handed to them by colleagues), partly from the Donetsk reg. (samples from nests of Buteo rufinus, passed by D. Pylypenko).

A set of cranial features allowing to distinguish East European mole-rat species was described in our previous works (Коробченко, Загороднюк, 2009; Коробченко, 2012). Among them, five characters are used in this research to distinguish the pair of S. zemni and S. microphthalmus; (Ukrainian acronyms are in parenthesis):

\footnotetext{
${ }^{1}$ Both samples represent older specimens with signs of fresh tissues, i.e. they are of modern age, not fossil.

${ }^{2}$ The type specimen of Spalax polonicus Mehely mentioned in the first revisions (Топачевский, 1969), but later it was considered as lost (Коробченко, 2014); its description will be presented in a separate communication.
} 
1) RLN (ВДН): relative length of the nasal bones;

2) PEN (ЗKH): proximal ends of the nasal bones (shape);

3) PNS (ПНШ): postnasal sutures (shape of frontonasal and frontomaxillary sutures);

4) POS (ЗОШ): postorbital sutures (the angle between coronal and frontosquamal sutures);

5) SIP (ФTК): shape of the parietal bones ${ }^{1}$.

Another character mentioned by V. Topachevsky (1969: p. 206, 217) has been added to the list too: the size of the auditory pore. In $S$. zemni it is of the same length as of the first molar teeth $\left(\mathrm{M}^{1}\right)$, but in $S$. microphthalmus its length is significantly smaller than the length of $\mathrm{M}^{1}$. Also, we have analyzed 3 new characters related to the occipital part of the skull:

6) DAP (ДВО) - the greatest diameter of the auditory pore (in relation to the coronar length of the first upper molar $\left.\mathrm{M}^{1}\right)$;

7) $\mathrm{COE}(\mathrm{CПГ):} \mathrm{expression} \mathrm{of} \mathrm{the} \mathrm{external} \mathrm{occipital} \mathrm{crest} \mathrm{(crista} \mathrm{occipitalis} \mathrm{externa);}$

8) SGH (ФПО): shape (contours) of the foramen magnum from back view;

9) LLS (БПВ): lateral occipital lines on the squamous part of the occipital bone.

We have measured the skulls by caliper, while measurements of small characters (auditory pore diameter and coronar length of $\mathrm{M}^{1}$ ) were carried out by eyepiece micrometer in binocular MBS-9. Photos were taken by a digital camera, photographing of skull parts was held by a digital microscope. When taking pictures of sutures we used contrasting by graphite (soft pencil). The distribution of all these features among the samples are presented in tab. 1.

\section{Results and discussion}

\section{Hypothesis}

The settlement of mole-rats on Khortytsia is considered as an old "refugium" in terms of biogeography of Spalax, which is situated between the ranges of Spalax zemni (right bank of the Dnipro) and S. microphthalmus (left bank of the Dnipro). This island population is a unique biogeographical fact which might be an evidence of ancient evolutionary events related to the migration of terrestrial steppe species in the area of Dnipro Rapids. The mole-rat forms on Khortytsia a relatively stable population (fig. 1), which is considered as autochthonous. The mole-rat is not a subject of human economic interest, and we do not know about cases of its artificial resettlement; it also avoids water. Therefore, the basis of our hypotheses is that mole rats on the island have remained from the time when the island was connected with one of the banks of the Dnipro river, either right (range of S. zemni), or left (range of S. microphthalmus).

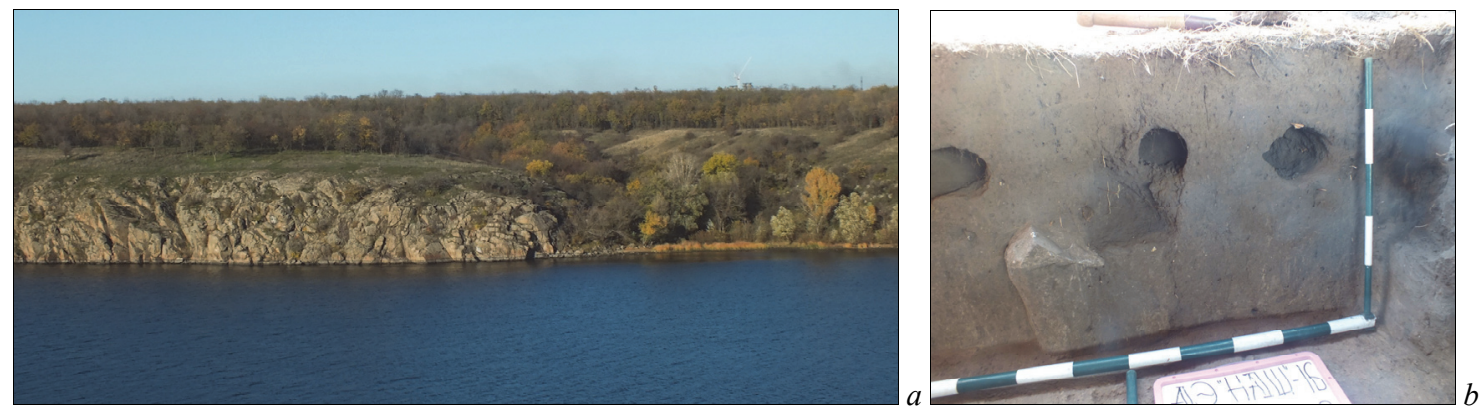

Fig. 1. A general view of a location inhabited by mole-rats on Khortytsia (photo taken from the right bank of the Dnipro river), and where a settlement exists $(a)$; archaeological section of the ancient monument Heneralka-2, with openings of tunnels of mole-rats $(b)$. Photos courtesy of O. Tuboltsev.

Рис. 1. Загальний вигляд одного з місцезнаходжень, в якому мешкають сліпаки на острові Хортиця (фото 3 правого берега Дніпра), на якому є поселення сліпаків (a), археологічний розріз стародавньої пам'ятки «Генералка-2», в якому відкриваються нори сліпаків $(b)$. Фотографії люб'язно представлено О. Тубольцевим.

${ }^{1}$ In reviews by E. Reshetnik (1941) and by V. Topachevsky (1969) these bones were named as parietals, which was accepted in our publications, but this bone is mentiomed as "interparietal" in: Ketani et al., 2017. 
It is obvious that each large river island is inhabited by a certain set of species that have existed in the region for a long time, even when some species became extinct or changed their ranges on adjacent lands due to significant alterations in the biome. Insular fauna have for this much fewer opportunities and, in fact, they are conserved and composed of species that were distributed in the region when the island had a connection with one of the banks. This primarily concerns exclusively terrestrial animals unable to fly and avoiding water, and it is fully refers to mole-rats, whose lifestyle is restricted to underground ecotopes. It is important that mole-rats occupy a very narrow econiche, so in one area always only one species is presented (Коробченко, Загороднюк, 2009). Hence, there is no reason to believe that such islands (including Khortytsia) could be inhabited by two mole-rat species simultaneously, but survived just one of them.

\section{The variety of status assessments for mole-rats from Khortytsia}

In the published fauna checklist of the Khortytsia National Reserve mole-rats are listed as "Spalax microphthalmus" (Перелік..., 2016). Passed to us samples are labeled also as "Spalax microphthalmus". In the review by V. Topachevsky (1969) this island, as well as the Middle Dnipro region in general, is not mentioned, and the descriptions of species' ranges are very schematic.

In the review on animals' distribution ranges in relation to the Dnipro, I. Tsemsh (Цемш, 1941) mentioned mole-rats as a pair of species separated by the river: S. polonicus (=zemni, westwards from the Dnipro) and S. microphthalmus (eastwards from the Dnipro). However, the researcher, in general, builds his concept on the old taxonomic basis: he assumes that Lower-Dnipro Sands (in the Left Bank) are also inhabited by S. podolicus, which was established by E. Reshetnyk as a subspecies S. polonicus zеmni (Решетник, 1939), and later as S. zеmni arenarius (Решетник, 1941). After the review by S. Ognev (Огнев, 1940, 1947), the sand mole-rat was recognized as a separate species S. arenarius, and later included into the species group "giganteus" (Топачевский, 1969). Therefore, the issue of transition of Podolian mole-rats over the Dnipro was closed. There had been no information about the existence of mole-rats on Dnipro islands for a long time, and Khortytsia was not mentioned in descriptions of mole-rats' distribution in the reviews by both E. Reshetnyk (Решетник, 1941) and V. Topachevsky (Топачевский, 1969).

\section{Analysis of samples and variants of characters}

The main attention has been paid to cranial characters that distinguish the pair of Spalax zemni and S. microphthalmus, and to determination of the place of mole-rats from Khotytsia and Zaporizhia in the space of variation of these characters. Data on morphotypes of cranial characters in the mole-rat from Khotytsia in comparison with typical variants in S. zemni and S. microphthalmus are summarized in tab. 1. It is necessary to remember that each character can be found in other states characteristic for some other species ${ }^{1}$ (Коробченко, 2012). In the sample from Khortytsia, all the characters are identical to typical characters of S. zemni; the same applies to samples from the vicinities of Zaporizhia. The dental features of the sample from Khortytsia cannot be analyzed because it is of old age with worn crowns. Below, these characters are analyzed in details.

Lengthening of the rostrum. Character RLN (relative length of the nasal bones) as a diagnostic peculiarity for the pair zemni/microphthalmus was analyzed by E. Reshetnyk (1941) and V. Topachevsky (1969). However, these researchers describe it differently: Topachevsky indicates that in microphthalmus the length of the nasal bones exceeds the joint length of the parietal and frontal bones. Reshetnyk indicates that the nasal length in this species is almost equal to the joint length of the frontal and parietal bones. Unlike S. microphthalmus, RLN in S. zemni is much smaller (in this both researchers agree). According to our data, in S. microphthalmus $\mathrm{RLN}=48.0-52.4 \%(\mathrm{n}=17)$, while in the sample from Khortytsia RLN $=44.6 \%$, and in the samples from Zaporizhia RLN = $42.9-48.3 \%(\mathrm{n}=5)$. Thus, samples from Khortytsia and Zaporizhia clearly differ from S. microphthalmus (fig. 2) and are similar to S. zemni (41.5-47.8 \%, $\mathrm{n}=14)$.

\footnotetext{
${ }^{1}$ In particular, the frequency of manifestation of "alien" character variants in S. microphthalmus, often considered as diagnostic to distinguish the species from other Spalax, is 2.2 to 26.7 \% (Коробченко, 2012).
} 
Table 1. Key cranial differences between the two species of mole-rats (after: Korobchenko, 2010) known on both banks of the middle course of the Dnipro, and expression of these characters in the mole rat from Khortytsia

Таблиця 1. Ключові краніальні відмінності двох видів сліпаків (за: Коробченко, 2010), відомих по різні боки середньої течії Дніпра, та прояви цих ознак у сліпака з Хортиці

\begin{tabular}{|c|c|c|c|}
\hline Character & Spalax zemni & Sample from Khortytsia & S. microphthalmus \\
\hline $\begin{array}{l}\text { RLN: relative length of the } \\
\text { nasal bones }\end{array}$ & $\begin{array}{l}\text { RLN3: much more than } \\
\text { the length of frontal }+ \\
\text { parietal bones }\end{array}$ & $\begin{array}{l}22.1 \text { against } 27.5 \mathrm{~mm} \text { ( } 44.6 \% \text { of } \\
\text { the joint length of frontal and } \\
\text { parietal bones), = zemni (fig. } 2 \text { ) }\end{array}$ & $\begin{array}{l}\text { RLN1*: more than the joint } \\
\text { length of the frontal and } \\
\text { parietal bones }\end{array}$ \\
\hline $\begin{array}{l}\text { PEN: proximal margins of } \\
\text { the nasal bones }\end{array}$ & $\begin{array}{l}\text { PEN3: narrowed, do not } \\
\text { form straddle-type split }\end{array}$ & $\begin{array}{l}\text { moderately narrowed, without } \\
\text { straddle-type split, = zemni } \\
\text { (fig. } 3 \mathrm{~b} \text { ) }\end{array}$ & $\begin{array}{l}\text { PEN4: blunt, not bifurcated, } \\
\text { often elongated beyond the } \\
\text { postnasal sutures }\end{array}$ \\
\hline $\begin{array}{l}\text { PNS: postnasal sutures (the } \\
\text { line of frontonasal and fron- } \\
\text { tomaxillary sutures) }\end{array}$ & $\begin{array}{l}\text { PNS2: the suture is arc- } \\
\text { like and curved forwards }\end{array}$ & $\begin{array}{l}\text { the suture is arc-like and broadly } \\
\text { curved forwards, = zemni } \\
\text { (fig. } 3 \mathrm{~b} \text { ) }\end{array}$ & $\begin{array}{l}\text { PNS: the suture is similar to } \\
\text { a straight line or curved } \\
\text { backwards, often ledged }\end{array}$ \\
\hline $\begin{array}{l}\text { POS: postorbital sutures } \\
\text { (angle between coronal and } \\
\text { frontosquamal sutures) }\end{array}$ & $\begin{array}{l}\text { POS3a: sutures form an } \\
\text { obtuse angle, or (rarely) a } \\
\text { right angle }\end{array}$ & $\begin{array}{l}\text { right angle (this character is little } \\
\text { informative, but a typical variant } \\
\text { for zemni) (fig. } 3 e \text { ) }\end{array}$ & $\begin{array}{l}\text { POS3b: sutures form an } \\
\text { obtuse angle }\end{array}$ \\
\hline $\begin{array}{l}\text { SIP: shape of the parietal } \\
\text { bones (p.b.) }\end{array}$ & $\begin{array}{l}\text { SIP3: p.b. are narrowed } \\
\text { and short forming an alm- } \\
\text { ost regular 5-pointed star }\end{array}$ & $\begin{array}{l}\text { p.b. are narrowed (age-depend- } \\
\text { ent character, the sample is se- } \\
\text { nex), generally = zemni (fig. } 3 e \text { ) }\end{array}$ & $\begin{array}{l}\text { SIP4: p.b. are wide and long } \\
\text { forming a regular 5-pointed } \\
\text { star }\end{array}$ \\
\hline $\begin{array}{l}\text { DAP: the greatest diameter of } \\
\text { the auditory pore }\end{array}$ & $\begin{array}{l}\text { DAP1: large, the greatest } \\
\text { diameter is longer than the } \\
\text { length of } \mathrm{M}^{1}\end{array}$ & $\begin{array}{l}\text { the greatest diameter equal or } \\
\text { longer than the length of } \mathrm{M}^{1} \\
=\text { zemni }(\text { рис. } 3 \mathrm{c})\end{array}$ & $\begin{array}{l}\text { DAP2: small, the greatest } \\
\text { diameter is smaller or (rare- } \\
\text { ly) equal to the length of } \mathrm{M}^{1}\end{array}$ \\
\hline $\begin{array}{l}\text { COE: expression of the exter- } \\
\text { nal occipital crest (crista oc- } \\
\text { cipitalis externa) }\end{array}$ & $\begin{array}{l}\text { COE1: the crest is not } \\
\text { developed (even in } \\
\text { adults)* }\end{array}$ & $\begin{array}{l}\text { the crest is absent (there are } \\
\text { small segments of bony ridges), } \\
=\text { zemni }\end{array}$ & $\begin{array}{l}\text { COE2: the crest is well- } \\
\text { developed (even in the } \\
\text { young) }\end{array}$ \\
\hline $\begin{array}{l}\text { SGH: the shape (contours) of } \\
\text { the foramen magnum }\end{array}$ & $\begin{array}{l}\text { SGH1: f. m. is trapezoidal, } \\
\text { extended upwards, its } \\
\text { upper contour is rounded }\end{array}$ & $\begin{array}{l}\text { f. m. is trapezoidal, extended } \\
\text { upwards, its upper outline is } \\
\text { rounded, almost straight, } \\
=\text { zemni }\end{array}$ & $\begin{array}{l}\mathrm{SGH} 2 \text { : the lateral margins } \\
\text { are parallel; the top line is } \\
\text { inflected (often a distinct } \\
\text { angle forming a pentagon) }\end{array}$ \\
\hline $\begin{array}{l}\text { LLS: lateral occipital lines on } \\
\text { squamous part of occipital } \\
\text { bone (angle of divergence) }\end{array}$ & $\begin{array}{l}\text { LLS1: the lateral lines } \\
\text { diverge under a slight } \\
\text { angle, to } 15-25^{\circ}\end{array}$ & $\begin{array}{l}\text { the lateral lines diverge upwards } \\
\text { under a slight angle (up to } 20^{\circ} \text { ), } \\
=\text { zemni }\end{array}$ & $\begin{array}{l}\text { LLS2: the lateral lines di- } \\
\text { verge upwards under a visi- } \\
\text { ble angle, ca. } 40-60^{\circ}\end{array}$ \\
\hline
\end{tabular}

* In Nannospalax nehringi this feature is sex-related, well-developed in males (Ketani et al., 2017).

Nasal bones and postnasal sutures. This complex includes two characters: the proximal edge of the nasal bones (PEN) and the shape of postnasal sutures (PNS) (tab. 1). In the specimen from Khortytsia, the character PEN corresponds to the morphotype PEN2, i.e. the proximal edge of the nasal bones is straight, without straddle-type split at the back and is not elongated beyond the postnasal sutures, so it corresponds to S. zemni. The same conclusion is true for the samples from Zaporizhia. Another character (PNS) in the samples from Krortytsia and Zaporizhia is also similar to S. zemni: sutures form almost a straight line, which is slightly curved forwards (i.e. towards the nose) as a wide arc. In the samples from Eastern Ukraine, which are typical S. microphthalmus, the line of nasal sutures is straight or slightly curved backwards, and the proximal edge of the nasal bones without a straddle-type split, and they usually not elongated beyond the postnasal sutures. Hence, mole-rats from Khortytsia and Zaporizhia (left bank) are similar to S. zemni.

Auditory pore (DAP). In diagnoses of S. zemni and S. microphthalmus presented by V. Topachevsky (1969), essential differences between the species were given according to the absolute and relative (in comparison with $\mathrm{M}_{1}$ ) size of the auditory pore. We have studied the variability of this character in our samples and we have found that samples of $S$. zemni from different parts of their range, including Khortytsia and Zaporizhia, are characterized by noticeably larger auditory pores. However, the reliability of this character is insignificant because of overlapping of the samples (fig. 2). It is also noticeable that the pore in S. microphthalmus not only smaller, but also rounded (round-shaped), while in $S$. zemni it is often elongated, elliptic. 

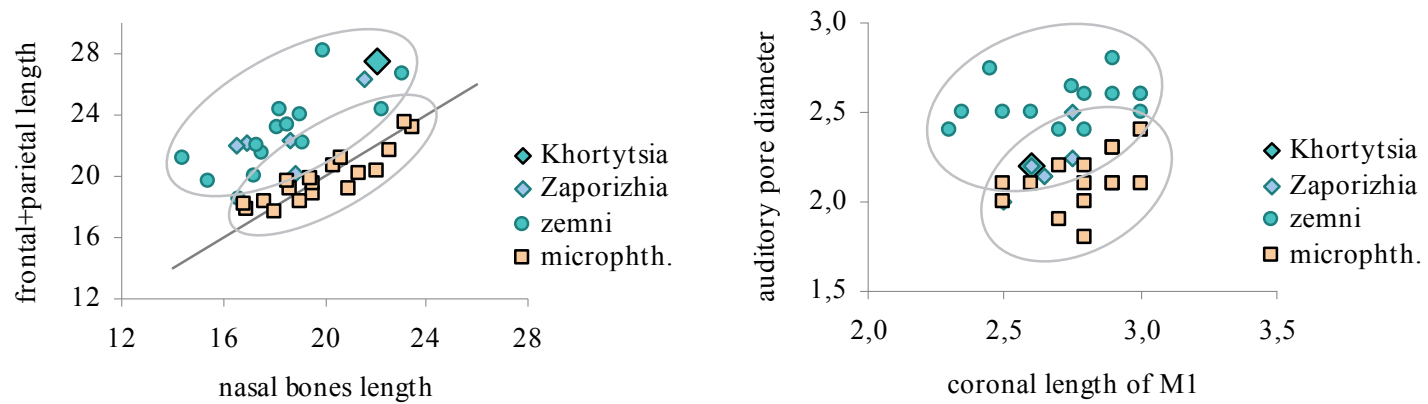

Fig. 2. Variation of two key characters in mole-rats from Khortytsia and Zaporizhia in comparison with $S$. zemni (from Right-Bank Ukraine) and S. microphthalmus (from Eastern Ukraine). Left — character RLN (relative length of the nasal bones); right - character DVO (ratio of the diameter of external auditory pore and the length of $\mathrm{M}^{1}$ ).

Рис. 2. Мінливість двох ключових ознак у сліпаків з Хортиці та Запоріжжя порівняно з S. zетni (Правобережжя) та $S$. microphthalmus (схід України). Ліворуч - ознака ВДН (відносний розмір носових кісток); праворуч - ознака ДВО (співвідношення діаметру зовнішнього вушного отвору та довжини $\mathrm{M}^{1}$ ).
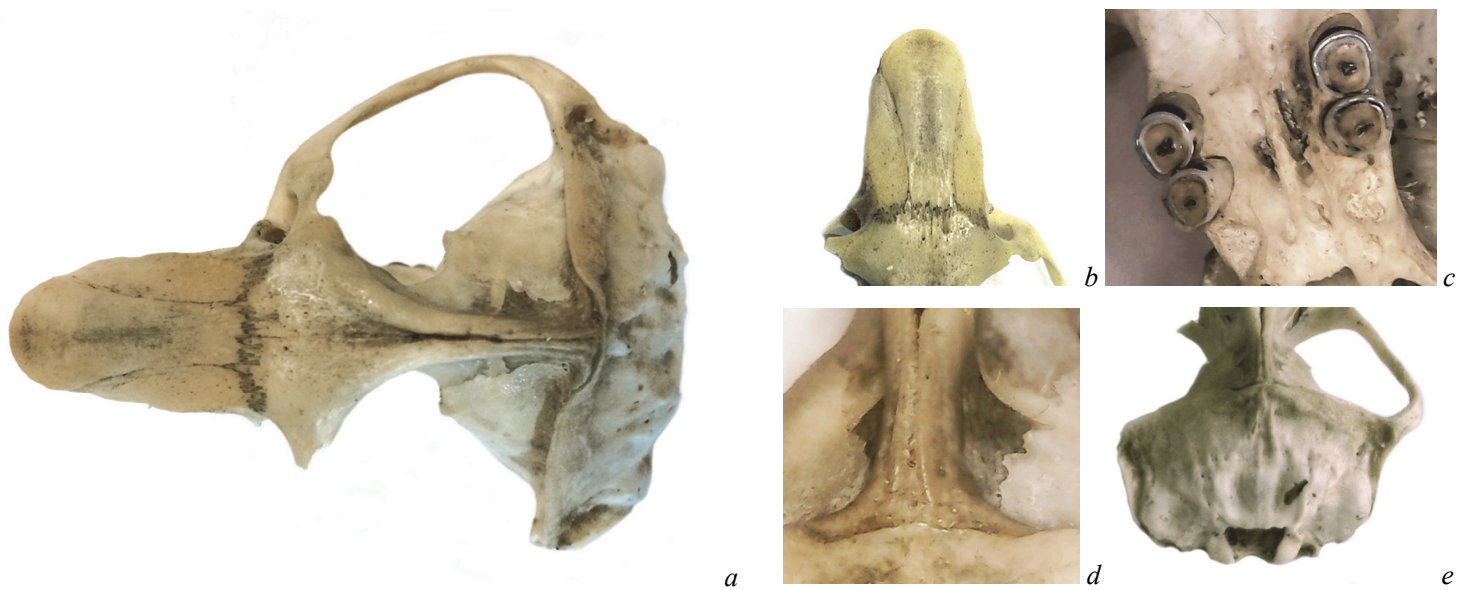

Fig. 3. Skull of Spalax sp. from Khortytsia: a) a general view from the top, b) the nasal bones and adjacent sutures (sutura frontonasalis); c) crowns of the upper molars; d) parietal bone; e) occipital area.

Рис. 3. Череп Spalax sp. з Хортиці: а) загальний вигляд з верху, b) носові кістки та прилеглі до них шви; c) коронки верхніх кутніх зубів, d) тім'яна кістка; е) потилична область.
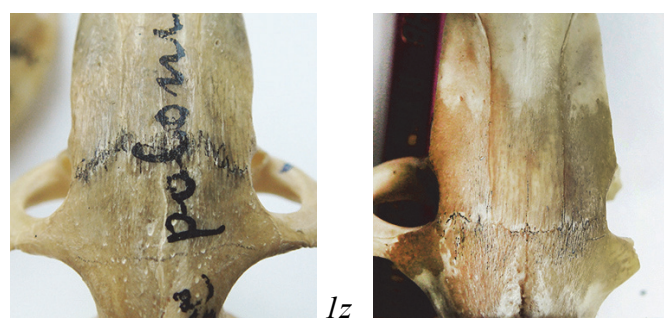

$1 m$
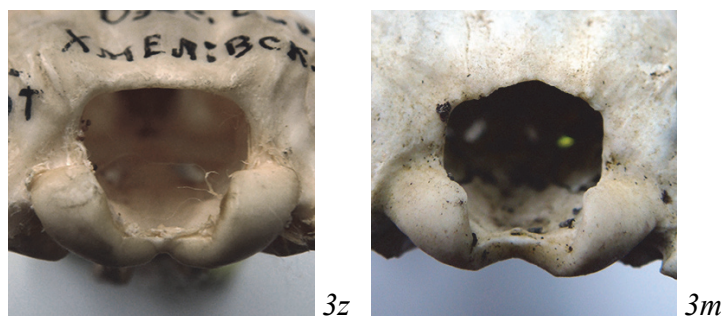
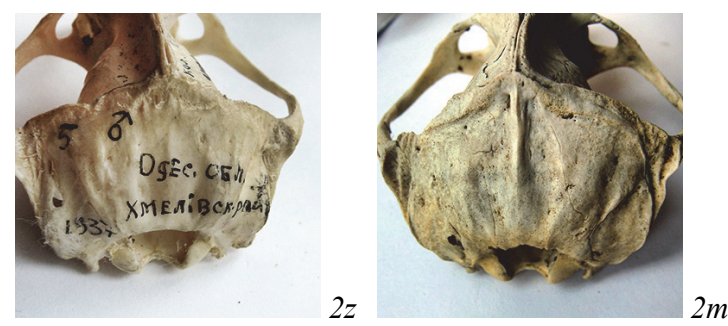

Fig. 4. Differences in skull morphology between Spalax zemni $(\mathrm{z})$ and S. microphthalmus (m): 1 - postnasal sutures (sutura frontonasalis); 2 - occipital crest (crista occipitalis externa); 3 - shape of the foramen magnum.

Рис. 4. Відмінності в будові черепа S. zетni (z) та S. microphthalmus (m): 1 - приносові шви, 2 - потиличний гребінь, 3 - потиличний отвір. 
Features of the occipital part. The temporal bones (character SIP, see tab. 1) in the mole-rat from Khortytsia are flattened laterally, just as in S. zemni. Three other diagnostic features for the pair zemni/microphthalmus were not described previously: 1) occipital crest (COE): in S. zemni and in the sample from Khortytsia the squamous part of the occipital bone is smooth, without a clear crest, while in S. microphthalmus there is a well-developed crest (crista occipitalis externa), extending from the top of the nuchal crest to the middle of the squamous part of the occipital bone; 2) shape of the foramen magnum (SGH): in S. zemni and in the sample from Khortytsia it is trapezoidal, extended upwards, its upper contour is rounded (in S. microphthalmus its lateral margins are parallel; the top line with inflection due to which the hole resembles a pentagon); 3) lateral occipital lines (LLS): on the squamous part of the occipital bone in S. zemni as well as in the sample from Khortytsia are almost collateral, diverging towards the nuchal crest (crista nuchae) under a slight angle (15$25^{\circ}$ ), but in $S$. microphthalmus these lines diverge under a greater angle, ca. $40-60^{\circ}$.

\section{Comparison of samples and diagnostically valuable characters}

The analysis of the complex of characters has showed that the mole-rats from Khortytsia and Zaporizhia (left bank) are identical to $S$. zemni. The described characters are stable and do not show significant geographical variation. Age-related peculiarities have little contribution into the general variability and do not affect significantly the accuracy of species identification. The individual variability of characters is essential, and for species identification we should consider a wide set of characters. Special importance should be given for two groups of cranial characters: (1) postnasal sutures and relative size of the nasal bones, and (2) morphological structures of the occipital area. In some cases, photos of the skull may be sufficient to identify the material. Spalax microphthalmus from Eastern Ukraine significantly differ from all other examined mole-rat samples which, as it turned out, belong to S. zemni (Khortytsia, right-bank parts of Zaporizhia and Dnipropetrovsk, also Kirovohrad, Mykolaiv, Ivano-Frankivsk and Lviv regions (including a type specimen of S. polonicus).

\section{Species records in the region}

The spatial relationship between the two mole-rat species in the area of Dnipro Rapids and the location of the mole-rat on Khortytsia are shown on the map (fig. 5). Range boundaries are outlined according to actual findings (data published before 2000 not included):

\footnotetext{
Spalax zemni: • z-D1 - Dnipropetrovsk reg., Nikopol dist. (2 skull in coll. of NMNH-paleo); $\bullet$ z-D2 Dnipropetrovsk reg., Nikopol dist., Pokrov city (data from the map in review: Bulakhov, Pakhomov, 2006); • z-Z1 - Zaporizhia dist., Bilenke vil., 2014 (V. Busel, S. Kozodavov, pers. com.); • z-Z2 Zaporizhia, left-bank part (5 skulls in coll. of N. Lebedeva); $\bullet$ z-Z3 - Khortytsia, archaeological section of ancient monuments Heneralka-2, numerous molehills and osteological samples $(1$ skull +1 mandible in coll. of O. Toboltsev); $\cdot$ z-Z4 - Khortytsia, molehills along windbreak near Cossack Sadyba, spring, 2016 (E. Chebotok, pers. com.); • z-Z5 - Dnipro-Zaporizhia highway, right bank of the Dnipro, 30.06.2010, direct observation (V. Kostiushyn, pers. com., photo).

Spalax microphthalmus: • m-D1 - Dnipropetrovsk reg., vicin. of Pervozvanivka vill., 2000-2009 (primary data lost); $・ \mathrm{~m}-\mathrm{Z1}$ - Zaporizhia reg., Komyshuvakha vill., towards Orikhiv vill., 2012, molehills along the highway (E. Chebotok, pers. com.); $\bullet \mathrm{m}-\mathrm{Z} 2-$ Zaporizhia reg., Orikhiv dist., molehills along Orikhiv-Tokmak highway, near Robotyne vill., 2012-2014, molehills along the highway (E. Chebotok, pers. com.), $\bullet \mathrm{m}-\mathrm{Z3}$ - Zaporizhia reg., the same, vicin. of Novoprokopivka vill., the same (and other localities along the highway towards Tokmak vill.).
}

\section{Biogeographic interpretations}

The island mole-rat settlement on Khortytsia is obviously ancient. We have no information about artificial resettlement of the species onto the island, therefore, we recognize that the settlement has been formed naturally. Although mole-rats are able to swim (own data), such behavior is not common for them. Therefore, emergence of island populations is possible only via separation of placore parts from the main banks inhabited by mole-rats. The history of formation of Khortytsia shows signs of its shift from the left to the right bank. But this history might be more complicated considering the possibility of repeated changes of the riverbed in the region of Rapids. 
We have a number of facts of obvious transitions of the ranges of strictly terrestrial vertebrate species through the Dnipro exactly in the region of the Dnipro Rapids near Zaporizhia (Zaporizhia Rapids). There are three clear examples of such transition: a settlement of the northern mole vole Ellobius talpinus (Коробченко та ін., 2014) and the great jerboa Allactaga major (Селюніна, 2008) in the Right-bank Middle Dnipro region, which are distributed mainly on the steppes eastwards from the Dnipro (i.e. in the Left-bank areas). In contrary, Lacerta viridis demonstrates a transition to the Left-Bank area, while its main range is located in the Right-bank area (Таращук, 1959). Contours of this lizard's range are very similar to Spalax zemni (see tab. 2).

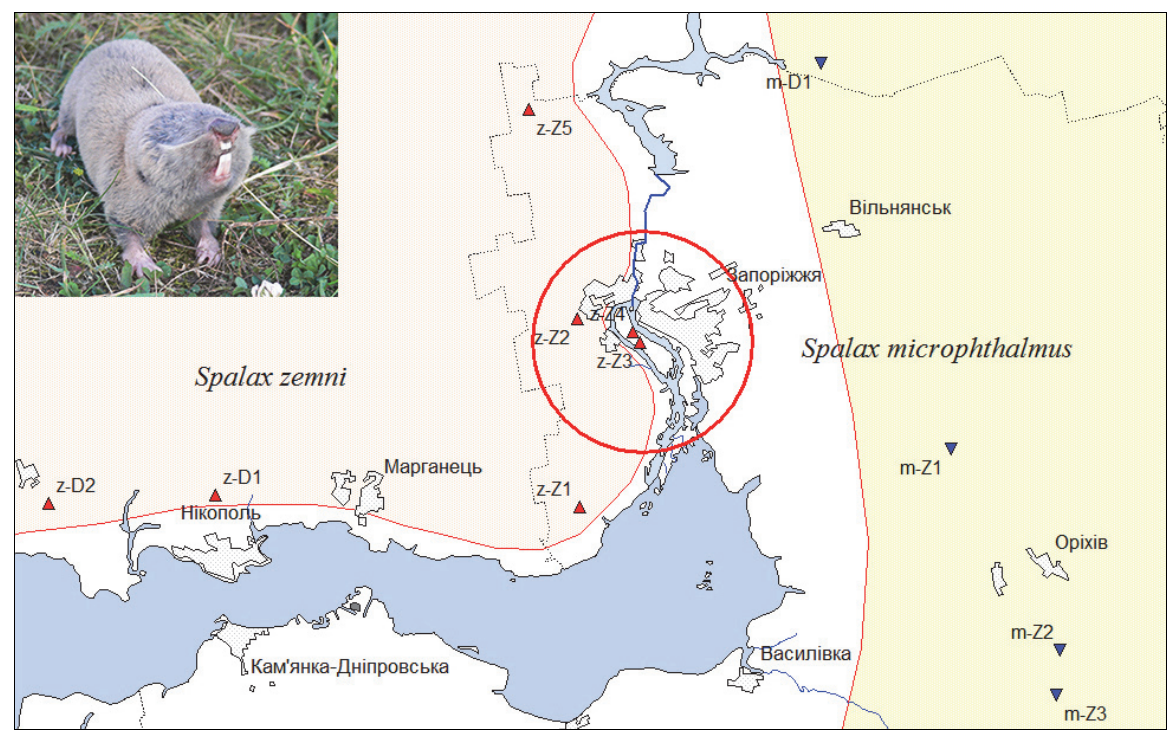

Fig. 5. Converge zone of ranges of two molerat species (Spalax zemni and S. microphthalmus) in the Middle Dnipro region and the location of Khortytsia (circle), where a settlement of S. zemni has been revealed.

Рис. 5. Зона сходження ареалів двох видів сліпаків (S. zemni та S. microphthalmus) y Середньому Подніпров'ї та місце розташування о. Хортиця (коло) 3 поселенням S. zemni.

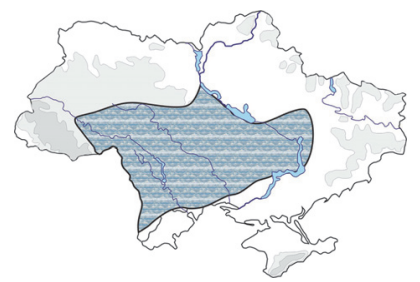

Fig. 6. Distribution of Lacerta viridis in Ukraine (after: Taraschuk, 1959). The range of this species in general coincides with the range of Spalax zemni, and this species is also known on Khortytsia.

Рис. 6. Поширення Lacerta viridis в Україні (за: Таращук, 1959). Ареал цього виду загалом збігається 3 ареалом Spalax zemni, і цей вид також відомий на Хортиці.

Table 2. Examples of species of terrestrial vertebrates whose range passed Dnipro Rapids

Таблиця 2. Приклади видів наземних хребетних, ареали яких переходять Дніпровські пороги

\begin{tabular}{|c|c|c|c|c|}
\hline Species & $\begin{array}{l}\text { Populations in Right- } \\
\text { bank Ukraine }\end{array}$ & $\begin{array}{l}\text { Populations on } \\
\text { Dnipro islands }\end{array}$ & $\begin{array}{l}\text { Populations in Left- } \\
\text { bank Ukraine }\end{array}$ & Explanations \\
\hline $\begin{array}{l}\text { Great jerboa, } \\
\text { Allactaga major }\end{array}$ & $\begin{array}{l}\text { in a system of arroyos } \\
\text { in the steppe towards } \\
\text { the Dnipro (Селюнi- } \\
\text { на, 2008) }\end{array}$ & absent & $\begin{array}{l}\text { in different steppe and } \\
\text { forest-steppe areas; } \\
\text { here is the main range } \\
\text { in Ukraine (Селюніна, } \\
\text { 2008) }\end{array}$ & $\begin{array}{l}\text { the main range is east- } \\
\text { wards from the Dnipro; the } \\
\text { species crossed the Dnipro } \\
\text { in the region of Rapids }\end{array}$ \\
\hline $\begin{array}{l}\text { Northern mole vole, } \\
\text { Ellobius talpinus }\end{array}$ & $\begin{array}{l}\text { in a system of arroyos } \\
\text { in the steppe towards } \\
\text { the Dnipro (Короб- } \\
\text { ченко та ін., 2014) }\end{array}$ & absent & $\begin{array}{l}\text { in different steppe } \\
\text { areas; here is the main } \\
\text { range in Ukraine (Kо- } \\
\text { робченко та ін., 2014) }\end{array}$ & $\begin{array}{l}\text { the main range is east- } \\
\text { wards from the Dnipro; the } \\
\text { species crossed the Dnipro } \\
\text { in the region of Rapids }\end{array}$ \\
\hline $\begin{array}{l}\text { Podolian and Greater } \\
\text { mole-rats, S. zemni and } \\
\text { S. microphthalmus }\end{array}$ & $\begin{array}{l}\text { S. zemni, widely } \\
\text { distributed westwards } \\
\text { from the Dnipro }\end{array}$ & $\begin{array}{l}\text { S. zemni, a stable } \\
\text { population on } \\
\text { Khortytsia (this } \\
\text { paper) }\end{array}$ & $\begin{array}{l}\text { S. microphthalmus, } \\
\text { widely distributed } \\
\text { eastwards from the } \\
\text { Dnipro }\end{array}$ & $\begin{array}{l}\text { the Dnipro is a barrier, } \\
\text { Khortytsia was occupied } \\
\text { by } S . \text { zemni }\end{array}$ \\
\hline $\begin{array}{l}\text { European green lizard, } \\
\text { Lacerta viridis }\end{array}$ & $\begin{array}{l}\text { typical settlements on } \\
\text { placore areas of the } \\
\text { right-bank steppe }\end{array}$ & $\begin{array}{l}\text { exists on Khortyt- } \\
\text { sia (Tаращук, } \\
\text { 1959; own data) }\end{array}$ & $\begin{array}{l}\text { a small segment of the } \\
\text { range in the region of } \\
\text { Dnipro Rapids }\end{array}$ & $\begin{array}{l}\text { the main range is west- } \\
\text { wards from the Dnipro; the } \\
\text { species crossed the river in } \\
\text { the region of Rapids }\end{array}$ \\
\hline
\end{tabular}


The issue of historic hydrography of the Lower Dnipro and its connection with distribution ranges of animals was repeatedly discussed both in the relation to the terrestrial fauna (Підоплічко, 1936; Цемш, 1941; Загороднюк, 1999) and to hydrobionts (Афанасьев, 2014). The dynamics of the watercourse also affected the distribution of subterranean rodents, including mole-voles (Коробченко та ін., 2014). Based on the distribution of the Podolian mole-rat (Spalax zemni) in the old wider understanding of its taxonomic scope (i.e. including S. arenarius), I. Tsemsh (1941) and E. Reshetnyk (1941) recognized that the species ${ }^{1}$ crossed the Lower Dnirpo to the left bank, which suggests the changes of its range, as well as of changes of the Dnipro's course. Tsemsh wrote about it directly, while Reshetnyk avoided discussions about the boundaries of ranges. Discussing the issues of impermeability of the Dnipro in relation to dispersal of steppe species and giving examples of such distribution patterns on both banks (marmot, jerboa, pika, ground squirrels), I. Pidoplichko (1936) did not mention mole-rats at all.

Despite this, the Dnipro river is a clear biogeographical coordinate in distribution of a number of steppe mammalians, in particular three mole-rat species (Загороднюк 1999). The studied material allows suggesting that in some cases "transitions" of mole-rats occurred across the riverbed. The Podolian mole-rat shows a biogeographical analogy with Lacerta viridis (fig. 6). Moreover, the range of the European green lizard "crosses" the Dnipro to the left bank in the region of Zaporizhia Rapids and possibly the same applies to the Podolian mole-rat ${ }^{2}$. We assume that S. zemni may occur in the Left-Bank Dnipro region, but the lack of morphological materials does not allow stating about it confidently. It is an important detail that species which crossed (according to our reconstruction) the Dnipro from east are absent on the islands, but the species which crossed the river from west are present on the islands and some adjacent left-bank areas.

Our analysis allows stating that mole-rat settlements on Khortytsia are evolutionary related to populations occurring on the right-bank steppe. We suggest the possibility of finding samples of Spalax zemni in the Left-bank Dnipro region.

\section{Acknowledgements}

We would like to thank L. Popova for the idea about possible existence of mole-rats on Dinpro islands and of the necessity of their identification, and also to our colleagues who have contributed to the study of mole-rat samples: N. Lebedeva, K. Redinov, O. Tuboltsev, and N. Cheremnykh. Our gratitude to $\mathrm{O}$. Tuboltsev for consultations regarding records of mole-rats on Khortytsia and for the photographs he provided. Our thanks to V. Busel, O. Harmash, S. Kozodavov, V. Kostiushyn, S. Mescheriakov, V. Ponomarenko, K. Redinov, V. Reminnyi, and Ye. Chebotok for consultations about findings of mole-rats. We also acknowledge Z. Barkasi for his help in taking microphotographs, for his participation in general discussions and proofreading the manuscript.

\section{References}

Афанасьев, C. А. Формирование гидробиоты речных систем на территории Украины в связи с историей гидрографической сети // Гидробиологический журнал. - 2014. - Том 50, № 5. - С. 3-14.

[Afanasyev, S. A. Formation of hydrobiota of the river systems in the territory of Ukraine in view of history of hydrographic net // Hydrobiological Journal (English version). — 2015. — Vol. 51, No. 1. — P. 3-12.]

Булахов, В. Л., Пахомов, О. С. Біологічне різноманіття України. Дніпропетровська область. Ссавці (Матmаlia). - Дніпропетровськ : Вид-во ДНУ, 2006. - $356 \mathrm{c.}$

[Bulakhov, V. L., Pakhomov, A. E. Biological Diversity of Ukraine. The Dnipropetrovsk Region. Mammals (Mammalia). - Dnipropetrovsk : Dnipropetr. Univ. Press, 2006. - 356 p. (In Ukr.)]

Загороднюк, I. B. Степове фауністичне ядро Східної Свропи: його структура та перспективи збереження // Доповіді НАН України. - 1999. — № 5. - С. 203-210.

\footnotetext{
${ }^{1}$ At that time it was called Spalax polonicus or S. podolicus (synonyms of S. zemni).

${ }^{2}$ According to the remarks of one of the peer-reviewers, the green lizard could be transferred to Khortytsia by birds. Regarding mole-rats, two cases are known when a buzzard was carrying mole-rats, and in both cases the animal got released. It happened in the Odesa region, in vicinities of Lisne vill., Tatarbunarsky dist., on 20.06.2016 (O. Harmash, pers. com.), and in the Luhansk region, in vicinities of Ivanivka vill., Antratsytivky dist., on 2.06.2007 (S. Mescheriakov, pers. com., the mole rat was alive).
} 
[Zagorodniuk, I. V. Steppe fauna core of Eastern Europe: its structure and prospects of protection // Reports of the National Academy of Sciences of Ukraine. — 1999. — No. 5. - P. 203-210. (In Ukr.)]

Коробченко, M. Мінливість та діагностична значимість краніальних ознак Spalax microphthalmus: порівняння з іншими видами Spalacidae зі Східної Європи // Праці Теріологічної Школи. — 2012. — Том 11. — C. $63-70$.

[Korobchenko, M. Variability and diagnostic value of cranial characters of Spalax microphthalmus: comparison with other Spalacidae species from Eastern Europe // Proceedings of the Theriological School. - 2012. — Vol. 11. — P. 63-70. (in Ukr.)]

Коробченко, М. Гризуни-землериї (Rodentia, Spalacidae et Ellobiusini) у зоологічних колекціях України // Збірник праць Зоологічного музею. - Київ, 2014. — № 45. - C. 70-78.

[Korobchenko, M. Burrowing rodents (Rodentia, Spalacidae et Ellobiusini) in zoological collections of Ukraine // Proceedings of the Zoological Museum. - Kyiv, 2014. - No. 45. - P. 70-78. (in Ukr.)]

Коробченко, М., Загороднюк, I. Таксономія та рівні диференціації сліпаків (Spalacidae) фауни України і суміжних країн // Науковий вісник Ужгородського ун-ту. Серія Біологія. — 2009. - Вип. 26. - С. 13-26. [Korobchenko, M., Zagorodniuk, I. Taxonomy and levels of differentiation in mole-rats (Spalacidae) of the fauna of Ukraine and adjacent countries // Scientific Bulletin of the Uzhgorod Univ. Ser. Biology. - 2009. — Vol. 26. - P. 13-26. (in Ukr.)]

Коробченко, М., Загороднюк, I., Редінов, К. Огляд поширення та морфометричні особливості сліпачка Ellobius talpinus (Arvicolidae) у Нижньому Подніпров’ї (Україна) // Праці Теріологічної школи. — 2014. — Том 12. - C. 89-101.

[Korobchenko, M., Zagorodniuk, I., Redinov, K. Review of distribution and morphometric peculiarities of the northern mole vole Ellobius talpinus (Arvicolidae) in the Lower Dnipro river region (Ukraine) // Proceedings of the Theriological School. 2014. - Vol. 12. — P. 89-101. (in Ukr.)]

Огнев, С. И. Систематические соотношения и проблема взаимного родства различных форм слепышей // Бюллетень МОИП. - 1940. - Том 49, № 2. - С. 33-41.

[Ognev, S. I. Systematic relations and the problem of the mutual relationship of various forms of mole-rats // Bulletin of MOIP. - 1940. - Vol. 49, No. 2. - P. 33-41. (in Rus.)]

Огнев, С. И. Семейство Spalacidae - слепыши // Огнев, С. И. Звери СССР и прилежащих стран. - Москва, Ленинград : Изд-во АН СССР, 1947. — Том 5. — С. 558-641.

[Ognev, S. I. Family Spalacidae - mole-rats // Ognev, S. I. Mammals of USSR and adjacent countries. — Moskva : Acad. Sci. USSR Press, 1947. - Vol. 5. - P. 558-641. (in Rus.)]

Перелік видів тварин // Національний заповідник Хортиця (веб-сайт). — 2016. — https://goo.gl/0SRYo5 [List of animal species // National Park Khortytsia (web-site). — 2016. — https://goo.gl/0SRYo5 (in Ukr.)]

Підоплічко, І. Г. Нові дані проти теорії про імпедитність р. Дніпра // Четвертинний період. — Київ, 1936. Вип. 11. - С. 75-83.

[Pidoplichko, I. G. New data against the theory about hindrance of the Dnipro river // Quaternary Period. — Kyiv, 1936. — Iss. 11. - P. 75-83.]

Селюніна, 3. В. Стан популяції тушканчика великого, Allactaga major, на півдні України // Знахідки тварин Червоної книги України / Ін-т зоол. НАН України; за ред. Г. В. Фесенка. — Київ, 2008. — С. 329-333. [Seliunina, Z. V. State of population of the Great Jerboa, Allactaga major, in the South of Ukraine // Registrations of Animals under Red Data Book of Ukraine / Inst. Zool. NAS Ukr.; G. V. Fesenko (ed.). — Kyiv, 2008. — P. 329-333. — (In Ukr.)]

Решетник, С. Г. До систематики і географічного поширення сліпаків (Spalacidae) в УРСР // Збірник праць Зоологічного музею. - Київ, 1939. - № 23. - С. 3-21.

[Reshetnyk, E. To the systematics and geographic distribution of mole-rats (Spalacidae) in the Ukrainian RSR // Proceedings of the Zoological Museum. - Kyiv, 1939. — No. 23. - P. 3-21. (In Ukr.)]

Решетник, С. Матеріали до вивчення систематики, географічного поширення та екології сліпаків (Spalacinae) УРСР // Збірник праць Зоологічного музею. - Київ, 1941. — № 24. - С. 23-95.

[Reshetnyk, E. Materials to study of systematics, geographic distribution and ecology of mole-rats (Spalacinae) in the Ukrainian RSR // Proceedings of the Zoological Museum. - Kyiv, 1941. - No. 24. - P. 23-95. (In Ukr.)]

Таращук, В. I. Земноводні та плазуни. — Київ : Вид-во АН УРСР, 1959. — 246 с. — (Фауна України; Том 7). [Taraschuk, V. I. Amphibians and Reptiles. - Kyiv : Ukr. Acad. Sci. Press, 1959. — 246 p. — (Fauna of Ukraine; Vol. 7)]

Топачевский, В. А. Слепышовые (Spalacidae). - Ленинград : Наука, 1969. - 248 с. — (Фауна СССР; Том 3 : Млекопитающие; Вып. 3).

[Topachevsky, V. A. Mole-Rats (Spalacidae). — Leningrad : Nauka, 1969. — 248 p. — (Series: Fauna USSR; Vol. 3: Mammals; Iss. 3). (in Ukr.)]

Цемш, I. О. До питання про значення Дніпра як зоогеографічної межі // Труди Зоологічного музею. - Київ : Вид-во Київського держ. ун-ту ім. Т. Г. Шевченка, 1941. — Том 1 (1939). - С. 307-311.

[Tsemsh, I. O. To the question about significance of Dnipro river as zoogeographical border // Acta Musei Zoologici. Kyiv : Kyiv State University Press, 1941. — Vol. 1 (1939). — P. 307-311. (in Ukr.)]

Ketani, Ş., Kilinç, M., Erdoğan, S. et al. A Macro-anatomical investigation of the some skull bones of Nehring's blind mole rats (Spalacidae: Nannospalax nehringi) // Anatomia, Histologia, Embryologia. — 2017. — Vol. 46, Iss. 1. - (in press). — https://goo.gl/OfGPJ6 